\title{
Effect of Audit Quality on Financial Performance: Evidence from Deposit Money Banks in Nigeria
}

\author{
Ezejiofor, Raymond A. \\ Department of Accountancy, Nnamdi Azikiwe \\ University, Awka, Nigeria
}

\author{
Erhirhie, Felix E. \\ Department of Accountancy, Nnamdi Azikiwe \\ University, Awka, Nigeria
}

\begin{abstract}
This study investigates the effect of audit quality on the financial performance of deposit money banks in Nigeria. The study adopted ex post facto research design, data for the study were collected from annual reports and accounts of quoted Nigerian deposit money banks. Regression analysis and coefficient correlation were employed to test the formulated hypotheses. Findings revealed that there is a significant effect between audit quality and financial performance of Nigerian deposit money banks. Based on this, the study recommends among others that the management of deposit money banks in Nigeria should increase the number of foreign directors that have skills, experience and would like to protect their integrity, reputation and professional competence.
\end{abstract}

Keyword: Audit Quality, Financial Performance, Deposit Money Banks in Nigeria

\section{INTRODUCTION}

The financial statement audit is a monitoring mechanism that assists in reducing the information asymmetry and protects the interests of the various stakeholders by providing them reasonable assurance that the financial statements are free from material misstatements. Meanwhile, the societal role of auditors is a key contribution to financial performance, in terms of reducing the risks of significant misstatements and by ensuring that the financial statements are elaborated according to fundamental rules and regulations, hence, lower risks on misstatements increase confidence in capital markets, which in turn lowers the firms cost of capital (Heil, 2012; Watts and Zimmerman, 1986).
Audit quality plays a significant role in maintaining an efficient market environment and independent quality audit underpins confidence in the credibility and integrity of financial statements which is essential for well-functioning markets and enhanced financial performance (Farouk \& Hassan, 2014).

Banks and other financial intermediaries are the heart of the world's recent financial crises. The deterioration of their asset portfolios, coupled with fraudulent acts of presenting fictitious financial statements and lack of adherence to corporate governance principles largely due to distorted credit management, were some of the main structural sources of the crises (Sanusi, 2010; Kashif, 2008; Fries, Neven \& Sea bright, 2002). This draws the attention of the public and investors to see the board of directors as the major actor responsible for the failure of corporations, both in developed and developing nations. In fact, board of directors are criticized for being responsible for mismanagement of shareholders' wealth, both in developed and developing economies, more especially, in Nigeria where this study is being conducted. They are seen as the fore-runner or prime factor for the fraud cases that had resulted in the failure of major corporations, such as Enron Corporation, Tyco International, WorldCom, Global Crossing, Arthur Anderson, Marconi, Parmalat, Oceanic bank plc, Wema bank plc, NAMPAK, Fin bank, Spring bank, Afribank, Intercontinental bank, Bank PHB and Cadbury PLC in Nigeria (Adeyemi \& Fagbemi, 2011; Ogbonna \& Ebimobowei, 2011; Ajibolade, 2008).

The questionable role of auditor's in ensuring the quality, reliability and credibility of financial 
performance has been a debate. This is because auditor's independence from their clients can be compromised or impaired through poor regulation of the auditing practice. Provision of non- audit services to the client, auditor's personal interest in the client's business among others. Thus effective and perceived qualities (usually designated as apparent quality) are necessary for auditing to produce beneficial effects as a monitoring device.

There is a limited study on the significant measures of audit quality and those of financial performance of deposit money banks in Nigeria. This makes the present study imperative and necessary at the moment as it seeks to fill the gap by investigating the effect of audit quality on financial performance of deposit money banks in Nigeria.

The aim of the study is to statistically examine the effect of audit quality on financial performance of quoted deposit money banks in Nigeria. The Specific objectives of the study are;

1. To determine the effect of audit committee size on return on equity of quoted Nigerian deposit money banks.

2. To examine the extent of which audit committee independent affect return on equity of quoted Nigerian deposit money banks.

\section{REVIEW OF RELATED LITERATURE Conceptual Framework} Audit Quality

Okaro, Okafor and Ofoegbu (2015) assert that audit quality is market-assessed joint probability that an auditor will both discover a breach in the client accounting system and also report the breach, this means that the auditor has both the technical competence to detect any material errors during the audit process, and the independence to ensure that material errors and omissions are corrected or disclosed in the auditor's report. In a like manner, Jackson, Moldrich and Roebuck (2008) view the quality of audits from actual and perceived quality.

DeZoort, Hermanson, Archambeault and Reed (2002) assert that larger audit firms are better than smaller audit firms at detecting errors because they have greater resources at their disposal and can attract employees with superior skills and experience. Audit quality therefore seems as auditors use some technics to recognize misstatements in clients accounting system and report the misstatements. Audit quality is that controversial issues for the recent decades and most previous evidence suggests that lack of audit quality is among the most important reason for financial and corporate scandals (Soltani, 2014).

Actual quality shows levels of risk of material errors in financial statements that can be reduced by the auditor. Perceived quality indicates the level of confidence of users in financial statement and the auditor's effectiveness in reducing material misstatement in financial statements prepared by management. Titman and Trueman (1986) see audit quality as the accuracy of the information reported by auditors. DeAngelo definition captures the role played by auditors in financial statement preparation. Hence, audit quality combines the ability of an auditor to detect a breach (auditor competence) and a willingness to report such a breach (auditor independence).

However, the Financial Reporting Council (FRC) (2006b) considers five factors that influence audit quality to includes: audit firm culture, skills and personal qualities of audit partners and staff, the effectiveness of the audit process, and the reliability and usefulness of audit reporting, amongst factor that are exogenous to the auditors.

Consequently, larger firms are able to conduct their audits to a higher standard than smaller firms. Thus audit quality (AQ) is dichotomous in nature and the size of audit firm (Big four or non-Big four) will be used as a proxy for audit quality (Ejeagbasi, et al, 2015). Further, this variable equals 1 if the external auditor of a deposit money bank in Nigeria is among the Big four (Deloitte, Ernst and Young, Price Water Coopers and KPMG) and 0 if otherwise.

\section{Composition of the Audit Committee}

Based on the Audit Committee, on the one hand internal auditing contribute to corporate governance by bringing best practice ideas of internal controls and risk management processes to the audit committee; providing information about any fraudulent activities or irregularities; conducting annual audits and reporting the results to the audit committee; encouraging audit committee in conducting periodic reviews of its activities and practices (Ejeagbasi, Nweze, Ezeh \& Nze, 2015). From the other hand, effective audit committees strengthen the position of the internal audit function by providing an independent and supportive environment and review the effectiveness of the internal audit function 
(Theofanis, George, Evaggelos \& Ioannis, 2010). The code provided for an audit committee that is expected to be effective and efficient. As such the composition of the audit committee is a dichotomous variable, assigned 1 if there are at least three non - executive directors on the audit committee, otherwise 0.

\section{Financial Performance}

There are several aspects of performance, each of which contributes to the overall performance in an organization. Despite the evolution of various available benchmarks and performance measurement, the answer to what is performance may still be hard to pin down. The banking sector aims for strong performance, but few banks worry about what constitutes such performance. The current run up of the stock market, at a time when corporate profits are fast declining, raises the question of whether or not banks are doing satisfactory good job for their shareholders (Ghouri \& Khan, 2011).

Hansen and Mowen (2005), states that firm performance is very essential to management as it is an outcome which has been achieved by an individual or a group of individuals in an organization related to its authority and responsibility in achieving the goal legally, not against the law, and conforming to the morale and ethic. Performance is the function of the ability of an organization to gain and manage the resources in several different ways to develop competitive advantage.

The main objective of financial performance measuring is to determine the operating and financial characteristics and the efficiency and performance of economic unity management, as reflected in the financial records and reports (Amalendu, 2010). Akinsulire, (2008) and Pandy (2003) points out that no performance review is beyond dispute, for instance, reported profit is a matter of opinion. If income is to be measured in terms of the increase or decrease in the wealth of an enterprise, obviously some definitions of that stock of wealth is required. Akinsulire, (2008) and Pandy, (2003) measures wealth in three categories; as financial capital - the equity stake in an enterprise in money terms; real financial capital, the equity stake in an enterprise in real terms (the proprietary concept); operating capacity capital, the ability of the enterprise to maintain its ability to provide goods and services (the entity concept). Hunger and Wheelan (1997) suggest performance as the end result of activity and the appropriate measure selected to assess corporate performance is considered to depend on the type of organization to be evaluated and the objectives to be achieved through that evaluation.

In addition, measuring performance is very important because it builds on the results, make different decisions in economic units. According to (Benjalux, 2006) performance measures are the life blood of economic units, since without them no decisions can be made. Financial performance Measure is one of the important performance measures for economic units. Financial performance measures are used as the indicators to evaluate the success of economic units in achieving stated strategies, objectives and critical success factors (Katja, 2009).

Performance measurement is therefore the process whereby an organization establishes the parameters within which programmes, investments, outputs and acquisitions are reaching the desired results (Hunger \& Wheelan, 1997). They further explain that performance measurement involves ongoing data collection to determine if a program is implementing activities and achieving objectives, the ongoing monitoring and reporting of program accomplishments, particularly progress toward preestablished goals (This is typically conducted by program or agency management) and a system for assessing performance of development interventions against stated goals. From the above, it could be affirmed that performance measurement is a measure or evaluation of achievement with predetermined or expected target of an organization. It can also be looked at as the process whereby a company establishes the parameters within which achievements, programmes, investments, outputs and acquisitions are reaching the desired results.

\section{Review of related Studies}

Farouk and Hassan (2014) examined the impact of audit quality on financial performance of quoted firms in Nigeria. Multiple regression analysis was employed in analyzing the data and testing the stated hypotheses. The results of the findings shows that auditor size and auditor independence have significant impacts on the financial performance of quoted cement firms in Nigeria. However, auditor independence has more influence than auditor size on financial performance.

Moutinho (2012) investigated the relationship between audit fees and firm performance. Using a 
sample of U.S. publicly traded, non-financial firms covering the period from 2000 to 2008 , a fixed effects model is presented to estimate firm operating performance. The model included standard control variables, such as size, leverage, sales growth and research and development intensity. In addition, measures of corporate governance were introduced. Specifically, increases (decreases) in operating performance are connected with decreases (increases) in audit fees.

Ziaee (2014) examined the relationship between audit quality and financial performance of companies in Iran. For this population the financial manager is accepted in Tehran Stock Exchange and 2008 to 2012 have been selected. Using primary data, he found that audit quality could affect the financial performance of companies.

Okoye, Okaro and Okafor (2015) studied corporate governance factors that affect audit quality, some of which if addressed will help in stemming the tide of audit failures. The study used secondary data extracted from the annual reports of a sample of 104 companies randomly selected from a population of 134 of non-bank companies listed in the Nigerian Stock Exchange, they concluded that small board size and greater board diligence impact positively on audit quality.

Yuniarti (2011) investigated the relation between factors that affect audit quality of 24 Bandung firm at 2009. He suggest that higher audit fees increase and improve audit quality due to auditors effort and accounting firm should enhance amount of audit fees that lead to higher audit quality. He also found that audit fees is significantly and positively affect audit quality.

Hoitash, Markelevich, \& Barragato (2007) examined the relationship between audit fees and audit quality. Their paper show that fees paid to auditor can impact in way; large fees paid to auditor increases quality of audit. Higher audit fees are related to non- audit service makes auditors more dependent on their clients. In their study, they examined audit fees for period of 2000 to 2003 and found that there is a significant positive relationship between audit fees and audit quality.

Modugu, Erahbhe and Ikhatua (2012) examine the relationship between audit delay and company characteristics in Nigeria. A sample of 20 quoted companies was selected for a period of 2009 to 2011 Ordinary Least Square technique was adopted in the analysis. The result revealed that multi-nationality connections of companies, company size and audit fees paid to auditors are the major determinants of audit delay in Nigeria. Also the paper revealed that audit report lag for each of the companies takes a minimum of 30 days and a maximum of 276 days for Nigerian companies to publish their annual reports. Nigeria listed companies take approximately two months on the average beyond their financial position date before they are finally ready for the presentation of the audited accounts to the shareholders at the annual general meetings.

Fagbemi and Uadiale (2011) study used a sample of forty-five audited financial statements of quoted companies. The data collected were analyzed using descriptive and inferential statistics. Findings revealed that the average number of days for which financial reports are ready after the year end is one hundred and forty-one days. The earliest time for which audit report is made ready after year end is thirty-one days afterwards. The result indicates a relationship between corporate reporting timelineness and company affiliation with a foreign entity. However, the results found no correlation between timeliness of financial statements, business complexity and business leverage.

Iyoha (2012) study the impact of company attributes on the timeliness of financial reports in Nigeria a sample of 61 companies' annual reports for ten (10) years were selected. The data were analyzed and results estimated using Ordinary Least Square (OLS) Regression. The findings reveal that the age of company is the major company attribute that influences the overall quality of timeliness of financial reports. It was also observed a significant difference in the timeliness of financial reporting among industrial sectors.

Egbunike and Abiahu (2017) determine the effect of audit firm characteristics on financial performance of money deposit banks in Nigeria. Specifically the study shall determine the effect of audit quality, audit fee, and audit report lag on return on assets of Nigerian banks. Next, ascertain the effect of audit quality, audit fee, and audit report lag on earnings per share of Nigerian banks. And finally, examine the effect of audit quality, audit fee, and audit report lag 
on net profit margin of Nigerian banks. The study adopted the ex post facto and correlational research design. The study population comprised all money deposit banks in existence as at 2015 financial year end. The study finds that audit quality has a significant effect on return on assets of Nigerian banks; Audit fee and audit report lag had no significant effect on return on assets, earnings per share and net profit margin of Nigerian banks.

Oladipupo (2011) investigated the extent of audit lag in Nigeria. Forty companies were selected. Both univariate and multivariate analyses were performed on the data collected. The study observed that; audit delay ranged from 16 to 284 days; Nigeria listed companies take approximately four months on the average beyond their balance sheet date before they are finally ready for the presentation of the audited accounts to the shareholders; That profitability, total assets, total debt, total equity, audit fees and industry type have no significant impact on audit delay.

Bouaziz (2012), examined the relationship between auditor size and financial performance on a sample of 26 Tunisian firms listed on the Tunis Stock Exchange. The result shows that auditor size has an important impact on the financial performance of firms in terms of return on assets and return on equity.

Miettinen (2011) examined the relationship between audit quality and financial performance. Audit quality was measured using auditor size and audit committee meeting frequency. The result shows that audit quality has both a direct effect as well as a mediated effect through audit size on financial performance. The results imply that measures of audit quality are not merely symbolic but that they contribute to financial performance.

Anderson and Verma (2012), examined the relationship between auditor size, auditor tenure and audit firm rotation using a probit model which they developed. The data they collected from 2,148 listed Asian companies shows that big audit firms provide high quality audit because big audit firms are more conservative than non-big audit firms. They also discovered that national level factors have a strong influence on audit quality. Auditor tenure is associated with impaired audit quality and audit firm rotation can help promote audit quality.
Woodland and Reynolds (2003) examined the association between indirect measures of audit quality and financial statement analysis using multivariate regression analysis. They found that audit fees is positively associated with financial statements but do not find evidence that auditor size, tenure or industry specialization are associated with audit quality in the directions predicted. Their results provide new evidence as to the current usefulness of these indirect measures in predicting audit quality.

Zureigat (2010) examined the effect of financial structure among Jordanian listed firms on audit quality. Using a sample of 198 companies, his analysis of logistic regression shows a significant positive relationship between audit quality and financial structure.

Nam (2011), examined the relationship between audit fees as a proxy for auditor independence and audit quality of firms in New Zealand. Employing three multiple regression models for a sample of New Zealand companies, his study discovered that the provision of non-audit services by the auditors of a firm comprises the auditor's independence, abnormal audit fee change rate is negatively associated with audit quality and auditor's independence of the previous year impacts on the audit fee that is negotiated in the current year.

Musa and Shehu (2014) examine the impact of audit quality on financial performance of quoted firms in Nigeria. The study is descriptive in nature and the correlational and ex-post facto designs were adopted in carrying out this research. Data were obtained basically from the published annual reports and accounts, and notes to the financial statements of the four firms that represent the sample of the study. The data collected were quantified and presented in tables. Multiple regression analysis using the SPSS Version 15.0 was employed in analyzing the data and testing the stated hypotheses. The results of the findings shows that auditor size and auditor independence have significant impacts on the financial performance of quoted cement firms in Nigeria. However, auditor independence has more influence than auditor size on financial performance.

Temple, Ofurum and Egbe (2016) examine the influence of audit committee characteristics on quality of financial reporting in listed Nigerian banks. The study used documentary records gotten from the 
financial statements of fifteen twelve-monthly reports and accounts of the banks whose stocks are traded in the Nigerian Stock Exchange as at December 31, 2014. The research design utilized in this dissertation is correlation research design. The investigator adopted Jones (1991) modified model which provided the measure for earnings management which is the representation for quality of financial reporting. The test of hypotheses and other breakdown of data were empirically completed by SPSS statistic 22.0. The outcomes of the study depicted that audit committee "independence has no significant effect on earnings management in quoted Nigerian banks.

Matoke and Omwenga (2016) sought to establish the relationship between audit quality and financial performance of listed companies in Nairobi Securities Exchange. This study adopted a descriptive research design. The sampling frame was drawn from directories of the Nairobi Securities Exchange Limited; consisting of all the 9 listed companies in Kenya. The study used simple random sampling to select 89 respondents since the study population was homogenous. Both primary and secondary data was used. After inspection, the data was coded and analyzed by the use of descriptive statistics and multiple linear regression analysis using SPSS. Findings of the study showed that the effect of audit quality on financial performance is positive and significant. The impact of auditor size was also positive and significant, although, its impact was lesser that of auditor independence.

Hamed, Rohaida, Siti Zaleha, and Mohamed (2016) examine the impact of audit quality on firm performance for Malaysian listed companies for the period of 2003 to 2012. In this study used audit fees and audit firm rotation as proxies for audit quality. Return on assets and Tobin's q are used as measures for firm performance. The study found that there is insignificant relationship between audit quality proxies (audit fees and audit firm rotation) and ROA. They also found that an audit fee is significantly and positively related to Tobin's Q. However, audit firm rotation is insignificantly related to Tobin's Q.

Chen (2003) investigated the relationship between Risk Based Internal Audit and corporate governance structures. It was found that there existed a significant positive relationship between the level of RBIA used and corporate governance bank's board size. The findings of this study indicated a significant negative correlation existed suggesting that a small board size seems to be more effective, and is more likely to use RBIA, as a complementary mechanism.

On contrary Krishnan, (2005) carried out an empirical analysis on the role of risk based audit on internal corporate governance and found that the percentage of non-executive directors and supervisors on the board of directors was significant negative associated with the use of RBIA indicating that the higher level of independent directors and supervisors on the board presents better corporate governance, hence may not employ higher percentage of RBIA for monitoring of risk management.

Okibo and Kamau (2011) carried out a study to explore internal auditors' compliance with Quality Assurance Standards: A case of state owned corporations in Kenya and found out that there is generally low compliance with quality assurance standards among most internal audit units in state owned corporations in Kenya. The research identified some of the reasons that led to low compliance to include; lack of awareness of standards; nonmembership with IIA; non-adoption of IPPF; age and experience of the internal audit department and understanding of the quality assurance standards.

Woodland and Reynolds (2003) examined the association between indirect measures of audit quality and financial statement analysis using multivariate regression analysis. They found that audit fees is positively associated with financial statements but do not find evidence that auditor size, tenure or industry specialization are associated with audit quality in the directions predicted. Their results provide new evidence as to the current usefulness of these indirect measures in predicting audit quality.

Abu Bakar et al., (2005) conducted a survey by among 116 loan officers in Malaysia. The results showed that 75.60 per cent of the respondents indicated that the size of the audit firm did affect the auditor independence and 74.40 per cent of them mentioned that the level of competition in the audit service market influenced the auditor independence. Furthermore, the results indicated that the provision of MAS had a negative effect on the auditor independence in Malaysia.

Nam (2011) examined the relationship between audit fees as a proxy for auditor independence and audit 
quality of firms in New Zealand. Employing three multiple regression models for a sample of New Zealand companies, his study discovered that the provision of non-audit services by the auditors of a firm comprises the auditor's independence, abnormal audit fee change rate is negatively associated with audit quality and auditor's independence of the previous year impacts on the audit fee that is negotiated in the current year.

Abu, Okpeh and Okpe (2016) study the influence of Board Characteristics on the Financial Performance of listed deposit money banks in Nigeria for the period of 2005-2014. The total number of listed deposit money banks as at 31 st December, 2014 are seventeen (17) out of which a sample of fifteen (15) were used for the study. Multiple regressions were used for the analysis of data collected from secondary source through the annual reports and accounts of the sampled banks. Findings revealed that foreign director is significantly and positively correlated or influenced the Performance of deposit money bank, while the grey director have negative significant effect on the Performance of deposit money banks in Nigeria. Other variables such as executive director, independent non-executive director $\bigcirc$ and women director have no significant impact on banks performance in Nigeria.

Bogale (2016) examine the determinants of external audit quality proxy by discretionary (abnormal) accrual based on audit firm specific and company related attributes in Ethiopian manufacturing share companies. The study adopted quantitative method of research approaches to test a series of research hypothesis. Specifically, the study used documentary analysis of companies' audited financial statements and personal inquiry with audit directors/officials of audit firms and company managers. The study selected a sample of eighteen (18) companies for the period of five years (2011-2015) with the total of 90 observations. The results of panel least square regression analysis show that certified audit professionals' and joint provision of audit and nonaudit services have statistically significant and positive relationship with manufacturing share companies' external audit quality. On the other hand, size of independent non-executive board members and duality of chief executive officers has a negative and statistically significant relationship with large manufacturing shares' external audit quality.
Yi-Fang, Lee-Wen, and Min-Ning (2015) investigate the relative importance between service quality and firm size in the performance determinants of audit firms under different market segments and business strategies. This study extracts a human capital-based service quality by the principal component analysis technique. In terms of market segment, total samples are divided into national, regional, and local audit firms. Further, based on the business strategies audit firms take, regional and local firms are classified into two categories: stability and expansion type firms. Empirical results indicate that service quality is a more important performance determinant than firm size in the national firms.

However, few studies have examined the significant measures of audit quality and those of financial performance of deposit money banks in developing economies such as Nigeria. This study is expected to fill an existing gap in knowledge by examining the effect of audit quality on the performance of quoted deposit money banks in Nigeria.

\section{METHODOLOGY \\ Research Design}

Ex-post facto research design was adopted for the study. This is appropriate because the study aims at measuring the relationship between one variable and another, in which the variables involved are not manipulated by the researcher.

\section{Population of the Study}

This study makes use of deposit money banks quoted on the Nigerian Stock Exchange. The study covered eight years annual reports and accounts of these companies from 2009 to 2016. The banks are as Access bank plc, Diamond bank plc, First bank plc, FCMB plc, GTB plc, Zenith bank plc, Sterling bank plc, UBA plc, Fidelity bank plc, Wema bank plc, Unity bank plc, Eco bank plc, Union bank plc, Skye bank plc and Stanbic IBTC.

\section{Method of Data Analysis}

The data for the study was collected from annual reports and accounts of deposit money banks quoted on the Nigerian Stock Exchange (NSE). The independent variable is audit quality (AQ).

Audit Quality (AUDQUA) = proxy using Audit Committee Size $($ ACSIZ) $=$ proxy using the number of members in the audit committee. It consists of those chosen from among the board of directors 
whose responsibility is to ensure that auditors' independence is kept. Audit Committee Independence $(\mathrm{ACIND})=$ proxy using the proportion of nondirectors on the board. While the financial performance as the dependent variable was proxy using return on equity (ROE).

\section{Model Specification}

The hypotheses formulated for this study were tested with the use of logistic regression. This was used to examine the relationship between dependent and independent variables.

The logistic regression for this study takes the form:

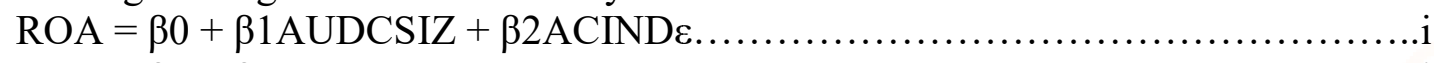

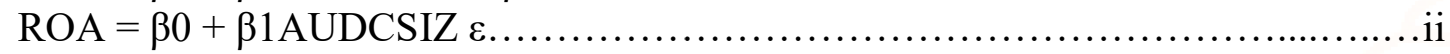

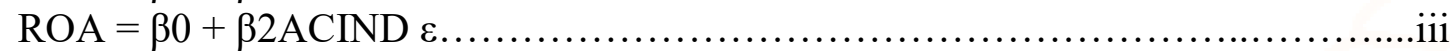

Where:

AUDCSIZ = audit committee size.

$\mathrm{ACIND}=$ audit committee independence.

FINPFM = financial performance proxy by Return on equity.

\section{ANALYSIS OF DATA}

Test of Hypotheses Formulated

Table 1: Model Summary

\begin{tabular}{|c|c|c|c|c|}
\hline Model & $\mathbf{R}$ & $\mathbf{R}$ Square & Adjusted R Square & Std. Error of the Estimate \\
\hline 1 & $.141^{\mathrm{a}}$ & .020 & .003 & .032560 \\
\hline
\end{tabular}

a. Predictors: (Constant), AUDIND, AUDSZE

Table 2: ANOVA ${ }^{\mathrm{a}}$

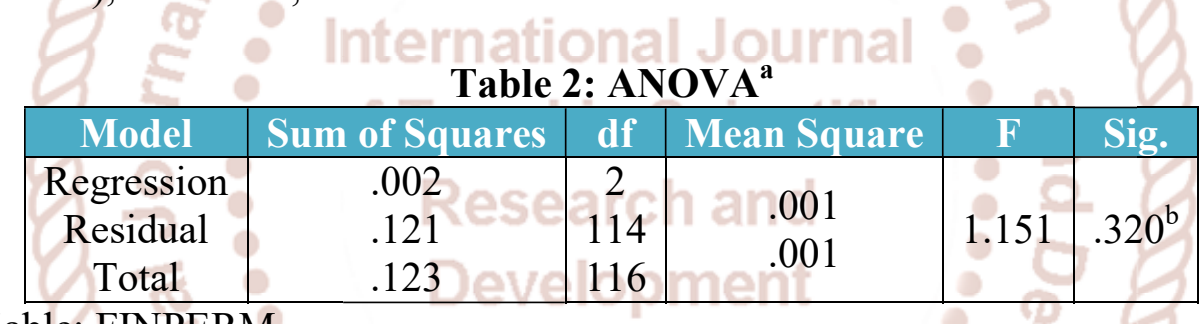

a. Dependent Variable: FINPERM

b. Predictors: (Constant), AUDIND, AUDSZE

Table 3: Coefficients ${ }^{\mathrm{a}}$

\begin{tabular}{|c|c|c|c|c|c|}
\hline \multirow{2}{*}{ Model } & \multicolumn{2}{|c|}{ Unstandardized Coefficients } & Standardized Coefficients & \multirow{2}{*}{$\mathrm{t}$} & \multirow{2}{*}{ Sig. } \\
\cline { 2 - 6 } & $\mathbf{B}$ & Std. Error & Beta & 1.937 & .055 \\
(Constant) & .084 & .043 & & -1.511 & .134 \\
AUDSZE & -.011 & .007 & -.143 & -.176 & .861 \\
AUDIND & .000 & .001 & -.017 & -17 \\
\hline
\end{tabular}

a. Dependent Variable: FINPERM

Table 1 above shows that the Model revealed the value of $\mathrm{R}^{2}=0.020$ and Adjusted $\mathrm{R}^{2}$ value is .003 this suggests that the model explains about $2 \%$ of the systematic variations in the dependent variable. This means that the regression explains $2 \%$ of the variance in the data. In table 2, it reveals that the F-stat (1.151) and p-value (0.320) indicates that the hypotheses of a statistically significant linear relationship between the dependent and independent variables cannot be rejected at 5\% level. In table 3, the regressed coefficient correlation result shows that an evaluation of the financial performance of the explanatory variable (Beta Column) shows that audit quality is positive and significant (Sig. $=1.050$ ). Therefore audit quality has a significant effect on financial performance of deposit money banks in Nigeria. Based on this, we reject null hypotheses and accept alternative with state that audit quality has effect on financial performance using return on equity of deposit money banks in Nigeria.

\section{Discussion of Findings}

From the results, audit quality (audit committee audit committee independence) has significant effects on 
the performance of quoted Nigerian deposit money banks. This result is in line with Ziaee (2014) who found that audit quality could affect the financial performance of companies. Also with Bouaziz (2012) result shows that auditor size has an important impact on the financial performance of firms in terms of return on assets and return on equity. Miettinen (2011) shows that audit quality has both a direct effect as well as a mediated effect through audit size on financial performance. Zureigat (2010) shows a significant positive relationship between audit quality and financial structure. Matoke and Omwenga (2016) findings indicate that the effect of audit quality on financial performance is positive and significant. Abu, Okpeh and Okpe (2016) findings show that foreign director is significantly and positively correlated or influenced the Performance of deposit money bank.

In contrary, Temple, Ofurum and Egbe (2016) indicate that audit committee "independence has no significant effect on earnings management in quoted Nigerian banks.

\section{CONCLUSION AND RECOMMENDATION}

This research work investigates the effect of audit quality on the financial performance of deposit money banks in Nigeria. The study provides empirical evidence of this effect within the Nigerian context. Findings from the study revealed that there is a significant positive effect between audit quality financial performance indices. The control variables; audit committee independence, audit reputation and firm size were found to be positively related to financial performance. This shows that the greater the degree of an auditors independence, the greater the propensity of a firm making substantial net profit margins.

Based on the findings of the study, the researcher recommends the followings:

Banks should make use of the services of audit firms with unquestionable track records as it concerns audit quality and audit reputation, one whose character and integrity is beyond question.

\section{Reference}

1. Abu, S. O., Okpeh, A. J. \& Okpe, U.J. (2016). Board characteristics and financial performance of deposit money banks in Nigeria. International Journal of Business and Social Science 7(9); September 2016159
2. Ahmed, A. A., \& Hossain, M. S. (2010). Audit report lag: a study of the Bangladeshi Listed Companies. ASA University Review, 4(4), $49-56$.

3. ronmwan, E.J., Ashafoke, T.O.\& Mgbame, C.O. (2013). Audit Firm Reputation and Audit Quality. Electronic copy available at: http://ssrn.com/abstract=2642722

4. Bell, T. B., R., Doogar \& Solomon, I. (2008). Audit labour usage and fees under business risk auditing", Journal of Accounting Research, 46(4) pp.729-760.

5. Carcello, J. V., \& Nagy, A. L. (2004). Audit firm tenure and fraudulent financial reporting. Auditing: A Journal of Practice and Theory, 23(2), 55-69.

6. Dogan, M., Coskun, E. and Celik, O. (2007). Is timing of financial reporting related to firm performance? - an examination on ISE Listed Companies. International Research Journal of Finance and Economics, Vol. 12, pp.220-233.

7. DeZoort, F. T., Hermanson, D. R., Archambeault, D.S. \& Reed, S.A., (2002). Audit committee effectiveness: a synthesis of the empirical audit committee literature', Journal of Accounting Literature, Vol. 21, p. 38-75, 2002.

8. De Angelo, L. (1981). Auditor size and audit quality. Journal of accounting and economics, 2 (1).

9. DeZoort, F. T. \& Salteerio, S. E. (2001). The effects of corporate governance experience and financial reporting and audit knowledge on audit committee members judgment." auditing: $A$ Journal of Practice and Theory. 20 (2): 31 - 47.

10. Egbunike, F. C. \& Abiahu, M. C.( 2017) Audit Firm Report and Financial Performance of Money Deposit Banks in Nigeria

11. Emekekwue, P. E. (2008). Corporate financial management. 5th Revised ed; Kinshasha: African Bureau of Educational Sciences.

12. Ekwe, M. C. \& Duru, A.N. (2012). Liquidity management and corporate profitability in Nigeria ESUT. Journal of Accountancy 3(1): 22 - 28.

13. Ejeagbasi, G E., Nweze, A.U; Ezeh, E.C. \& Nze, D. O. (2015). Corporate governance and audit quality in Nigeria: evidence from the banking industry European Journal of Accounting, Auditing and Finance Research 5(1).

14. Farouk M. A. \& Hassan, S., U. (2014).Impact of Audit Quality and Financial Performance of Quoted Cement Firms in Nigeria International 
Journal of Accounting and Taxation June 2014, Vol. 2, No. 2, pp. 01-22

15. FRC (2006), Promoting Audit Quality, Discussion Paper, London: Financial Reporting Council.

16. Falope, O. \& Ajilore, O.T. (2009). Working capital management and corporate profitability: Evidence from panel data analysis of selected quoted firms in Nigeria Research Journal of Business Management 3(3): 73 - 84.

17. Heil, D. (2012). The influence of the auditor on the earnings quality of their clients. (Umpublished Master's Thesis). Department of Accounting, Auditing and Control, Erasmus University, Rotterdam.

18. Jackson, A. B., Moldrich, M., \& Roebuck, J. K. (2008). Audit-firm tenure and the quality of financial reports. Contemporary Accounting Research, 19 (4), $637-660$.

19. Jensen, M.C. \& Meckling, (1976). Fama \& Jensen, 1983; Jensen, (1993). Theory of the Firm: Managerial Behavior, Agency Costs and Ownership Structure. Journal of financial economics, October, 1976, 3(4) pp. 305-360.

20. Lazaridis, I \& Tryfonidis, D (2006). Relationship between working capital management and profitability of listed companies in the Athens Stock Exchange Journal of Financial Management and Analysis 19(5): 26 - 35 .

21. Karaduman, H. A; Akbas, H. E; Caliskan, A. O \& Durers (2011). The relationship between working capital management and profitability: Evidence from an emerging market International Research Journal of Finance and Economics 62: 61 - 67.

22. Matoke V. N. \& Omwenga, J. (2016). Audit Quality and Financial Performance of Companies Listed in Nairobi Securities Exchange International Journal of Scientific and Research Publications, Volume 6, Issue 11, November 2016 372 ISSN 2250-3153 www.ijsrp.org

23. Moutinho, V. N. (2012), Audit fees and firm performance. Dissertação do Mestrado em Finanças e Fiscalidade, Faculdade De Economia, Universidade Do Porto

24. Sanusi, L. S. (2010). The Nigerian banking industry: what went wrong and the way forward" (Being the full text of a Convocation Lecture delivered at the Convocation Square, Bayero University, Kano.

25. Stanley, J. D. (2011). Is the audit fee disclosure a leading indicator of clients' business risk?"
Auditing: A Journal of Practice \& Theory, 30(3), pp.157-179.

26. Singh, J.P. \& Pandy, S. (2008). Impact of working capital management in the profitability of Hindalco industries Limited. The IUP Journal of financial Economics 6(4): 62 - 72.

27. Titman, S. \& Trueman, B. (1986). Information quality and the valuation of new issues. Journal of Accounting and Economics, 8 (2), 159 - 172.

28. Temple, M., (2016). The impact of audit committee size on the quality of financial reporting in quoted Nigerian banks. International Journal of Advanced Academic Research | Social \& Management Sciences | ISSN: 2488-9849 2(5) (May 2016)

29. Temple, M., Ofurum, C. O. \& Egbe, S. (2016). Audit committee characteristics and quality of financial reporting in quoted Nigerian banks. International Journal of Advanced Academic Research | Social \& Management Sciences | ISSN: 2488-9849 2(5) (May 2016)

30. Okaro, S. C., \& Okafor, G. O. (2015), Cultural Factors and Audit Quality - Evidence from Nigeria. International Journal of Academic Research IC in Accounting, Finance and Management Sciences, 5(2), 17-22. doi:10.6007/IJARAFMS/v5-i2/1558

31. Okaro, S. C., Okafor, G. O. \& Of oegbu, G.N. (2015), the effect of joint audit on audit quality the - perceptions of accountants, auditors and accounting academics. Paper presented at the African Accounting and Finance Association AAFA, 2015 Conference at Mauritius. DOI: 10.13140/RG.2.1.2695.6009

32. Okoye, E. I, Okaro, S. C., Okafor, G. O. (2015), Corporate Governance and Audit Quality. Paper presented at the Institute of Chartered Accountants of Nigeria First Academic Conference in Lagos. Available through Research gate.

33. Watts, R. L \& Zimmermen, J. (1986). Positive accounting theory. Engle wood Cliffs: Prentice Hall. 